\title{
PEMBANGUNAN MAMPAN PELANCONGAN MARITIM DI PULAU PERHENTIAN, TERENGGANU (SUSTAINABLE TOURISM DEVELOPMENT AT PERHENTIAN ISLAND, TERENGGANU)
}

\author{
Muhammad Faiz Ramli \& Hanizah Idris \\ Department of Southeast Asian Studies \\ Faculty of Arts and Social Sciences \\ University of Malaya \\ (wafa@um.edu.my)
}

\begin{abstract}
The marine park is one of the main tourist attractions in Malaysia, especially in the category of maritime tourism and special interests. The diversity and the natural beauty of the marine park at Pulau Perhentian, Terengganu, had successful attracting tourists from all around the world. The island is known for its marine activities like swimming, snorkeling, and scuba diving because of its clear and saline water. This situation will lead to the need to form a sustainability tourism development to maintain its natural environment and ecosystem so that tourists will be able to enjoy the natural beauty offered on the island. This process of sustainable development also minimises the damage that had been done to the existing ecosystem in the isle. Therefore, the sustainable development concept is crucial to sustaining every aspect of the tourism related program, specifically on islands such as Pulau Perhentian. The implementation of the National Ecotourism Plan (NEP) in 1997 by The Ministry of Tourism and Culture to cover the aspects of marine parks and islands remains crucially important towards sustainable tourism development in Malaysia.
\end{abstract}

Keywords: tourism, destinations, sustainable development, ecotourism, marine park 


\section{Pengenalan}

Pelancongan merupakan sebuah industri yang sedang berkembang maju di dunia termasuk di Malaysia. Ini disebabkan oleh pertumbuhan ekonomi global yang semakin baik, di samping peningkatan dalam kualiti hidup penduduk dunia seperti kadar pendapatan, kesihatan dan waktu terluang. Kesan daripada keadaan ini, mereka berupaya melakukan perjalanan ke setiap pelusuk dunia untuk bercuti, rekreasi dan tujuan-tujuan lain. Justeru, pelancongan dilihat mampu menjadi ejen perubahan terhadap landskap ekonomi, alam sekitar dan sosial sesebuah kawasan atau destinasi. Selain itu, ia dapat mewujudkan pusatpusat pertumbuhan baru yang berkaitan dengan aktiviti pelancongan maritim seperti yang terdapat di Pulau Perhentian, Terengganu. Ia juga mampu menyediakan peluang pekerjaan dalam bidang keusahawanan kepada penduduk tempatan dengan menggunakan sumber jaya sedia ada sebagai tarikan pelancong. Kepesatan industri ini secara langsung telah menyumbangkan kesan positif terhadap ekonomi, alam sekitar dan sosial destinasi yang dikunjungi oleh pelancong. Oleh itu, kerajaan telah mensasarkan pembangunan pelancongan tertumpu di kawasan-kawasan luar bandar disebabkan lokasi ini mempunyai kekayaan alam semulajadi dan warisan kebudayaan yang perlu dibangunkan secara mampan.

\section{Pembangunan Pelancongan Mampan}

Pembangunan mampan merupakan salah satu agenda penting dalam Pelan Ekopelancongan Kebangsaan (PEK) yang perlu diaplikasikan kepada semua bentuk pembangunan pelancongan yang dijalankan di Malaysia. Mengikut World Commission on Environment and Development (WCED) (1987) memberikan maksud pembangunan mampan seperti berikut:

"Development that meets the needs of the present without compromising the ability of future generations to meet their own needs."

Sementara itu, maksud pembangunan pelancongan mampan adalah:

"Tourism which is developed and maintained in an area (community, environment) in such a manner and at such a scale that it remains viable over and indefinite period and does not degrade or alter the environment (human and physical) in which it exists to such a degree that it prohibits the successful development and well-being of other activities and processes"(Weaver, 1998). 
Merujuk kepada definisi di atas, pembangunan mampan dan pelancongan mampan mempunyai persamaan dalam aspek memenuhi keperluan (individu atau pelancong) dan penggunaan sumber jaya secara optimum seperti tanah, air, tumbuhan dan tarikan pelancongan lain. Bagi mencapai tahap kemampanan bagi dua aspek ini, sumber jaya pelancongan yang sedia ada perlu digunakan bagi memenuhi kepuasan pelancong. Walaupun begitu, penggunaan sumber jaya ini perlu melalui proses perancangan yang selari dengan PEK supaya dapat menyumbangkan kesan positif terhadap ekonomi, alam sekitar dan sosial serta dapat dinikmati oleh generasi masa hadapan (Ibrahim \& Ahmad, 2012).

Istilah kemampanan pada awalnya digunakan untuk memberi penekanan kepada pengekalan sumber asli. Kemampanan bererti keupayaan untuk mengekalkan sesuatu, memastikan kewujudan atau memanjangkan. Tetapi konsep awal kemampanan ini diperkembangkan lagi dengan mengambil teori ekologi sebagai dasar kepada pembangunan mampan. Kemudian ia diperkembangkan lagi untuk meliputi dimensi teknikal, pengurusan, ekonomi, sosial, kemanusian, kebudayaan, etika dan institusi (UMT, 2012).

\section{Proses Pembangunan Pelancongan Mampan di Pulau Perhentian}

Ketibaan pelancong yang sentiasa mendadak dari tahun ke tahun telah memaksa kerajaan meningkatkan proses pembangunan pelancongan mampan di beberapa destinasi utama pelancongan di Malaysia. Ketibaan pelancong ke Malaysia meningkat saban tahun walaupun berlaku pelbagai perkembangan dalam ekonomi semasa seperti krisis ekonomi Asia yang melanda sebahagian negara Asia Tenggara termasuk Malaysia pada tahun 1997 hingga 1998 dan yang terkini krisis kewangan global di Amerika Syarikat pada tahun 2008 hingga 2009. Dengan pelbagai insentif yang telah diperkenalkan oleh pihak kerajaan, Malaysia terus menjadi destinasi utama para pelancong dengan jumlah ketibaan pelancong mencecah 29 juta pelancong pada tahun 2015 dengan jumlah pendapatan yang diterima sebanyak RM89 bilion. Hal ini menunjukkan wujudnya seseuatu yang menarik minat pelancong untuk ke Malaysia (Mohd. Ariff, Selvaraju, \& Md. Yusop, 2005).

Menyedari hakikat ini, pihak kerajaan Malaysia berusaha untuk meneruskan proses pembangunan pelancongan mampan terhadap destinasidestinasi utama pelancongan negara termasuklah Pulau Perhentian. Namun begitu, proses pembangunan pelancongan tidak dapat lari daripada 
meninggalkan impak negatif terhadap pelbagai aspek. Impak negatif ini terhasil ekoran aktiviti pelancongan yang dijalankan. Jika tidak dibendung ianya mampu untuk mengancam perkembangan sesebuah destinasi pelancongan dalam tempoh jangka masa panjang terutamanya destinasi yang melibatkan pelancongan sumber alam dan ekosistem seperti Pulau Perhentian. Hal ini kerana, sumber alam dan ekosistem adalah elemen yang sangat sensitif dan mudah berubah mengikut keadaan dan masa. Kerosakan sumber jaya, kesesakan, pencemaran yang berlaku akan mewujudkan persekitaran yang tidak selesa kepada pelancong dan juga komuniti setempatdi Pulau Perhentian. Sehubungan itu, terdapat garis panduan melalui Pelan Ekopelancongan Kebangsaan dalam membentuk pembangunan pelancongan mampan yang boleh digunakan dalam mengurangkan kesan negatif hasil dari proses pembangunan pelancongan di Pulau Perhentian.

Mengikut Jabatan Perangkaan Bandar dan Desa, hampir 50\% penduduk Pulau Perhentian terlibat dalam sektor pelancongan, $45 \%$ terlibat dlam sektor perikanan dan 5\% dalam sektor awam dan runcit (1997). Manakala purata pendapatan penduduk pula berbeza mengikut jenis pekerjaan yang diceburi. Misalnya, mengikut Rancangan Pembangunan Pulau-pulau Peranginan Malaysia, Jabatan Perangkaan Bandar dan Desa (1997), purata pendapatan nelayan adalah sebanyak RM300-RM400 sebulan berbanding RM40,000 bagi pengusaha Chalet (Nanthakumar, \& Thirunaukarasu, 2005) Namun perubahan mula berlaku dengan beberapa proses pembangunan pelancongan yang dijalankan oleh pihak kerajaan di Pulau Perhentian. Lihat Jadual 1.

Jadual 1: Jantina dan Jenis Kegiatan Ekonomi yang Dijalankan

\begin{tabular}{|l|l|l|l|l|l|}
\hline & \multicolumn{3}{|c|}{ JENIS KEGIATAN EKONOMI } & JUMLAH \\
\hline JANTINA & PERNIAGAAN & PELANCONGAN & PERIKANAN & $\begin{array}{l}\text { LAIN- } \\
\text { LAIN }\end{array}$ & \\
\hline LELAKI & 80 & 70 & 19 & 0 & 169 \\
\hline PEREMPUAN & 30 & 112 & 0 & 9 & 81 \\
\hline TOTAL & $\mathbf{1 1 0}$ & $\mathbf{1 1 2}$ & $\mathbf{1 9}$ & $\mathbf{9}$ & $\mathbf{2 5 0}$ \\
\hline Peratusan & $\mathbf{4 4} \%$ & $\mathbf{4 4 . 8} \%$ & $\mathbf{7 . 6} \%$ & $\mathbf{3 . 6} \%$ & $\mathbf{1 0 0 \%}$ \\
\hline
\end{tabular}

Sumber: Kajian Lapangan, 2015.

Mengikut Jadual 1 di atas, soal selidik dijalankan terhadap komuniti setempat di Pulau Perhentian untuk mengetahui taraf ekonomi berdasarkan jantina dan jenis kegiatan ekonomi yang dijalankan, namun boleh disimpulkan bahawasanya aktiviti ekonomi penduduk mulai mengalami perubahan dan lebih pelbagai semenjak 1997 terutamanya melalui langkah-langkah pembangunan yang dilakukan oleh kerajaan. Pada tahun 2015, penduduk 
semakin dilihat menceburkan diri dalam bidang perniagaan yang mewakili $44 \%$ daripada penduduk, dan dalam sektor pelancongan pula sebanyak $44.8 \%$ menjadikannya kegiatan ekonomi utama penduduk. Namun yang paling ketara adalah penglibatan penduduk dalam aktiviti perikanan iaitu $45 \%$ pada 1997 menjunam kepada 7.6\% pada 2015. Hal ini merupakan antara bukti kejayaan pihak kerajaan dalam mewujudkan kepelbagaian aktiviti ekonomi penduduk melalui proses pembangunan yang dijalankan di Pulau Perhentian.

\section{Had Daya Tampungan (Carrying Capacity)}

Had daya tampung digunakan bagi mengawal jumlah kemasukan pelancong ke sesebuah kawasan pada satu-satu masa. Ini memastikan kawasan yang dikunjungi terpelihara daripada kerosakan akibat aktiviti pelancongan. World Tourism Organisation (1992) begitu menekankan konsep Tourism Carrying Capacity yang bermaksud:

\section{"The maximum number of people that may visit a tourist destination at the same time, without causing destruction of the physical, economic, socio cultural environment and an unacceptable decrease in the quality of visitors' satisfaction"(WTO 2015).}

Dalam sains sosial, salah satu fungsi konsep ini adalah untuk mengukur setakat mana sumber asli dapat menampung populasi manusia di sesebuah destinasi pelancongan.

Jadual 2: Dimensi Utama Had Daya Tampungan

\begin{tabular}{|l|l|}
\hline Dimensi & Huraian \\
\hline Fizikal & $\begin{array}{l}\text { Menumpukan kepada ruang fizikal dan infrastruktur di } \\
\text { sesebuah destinasi. Ia meliputi kuantiti dan kualiti } \\
\text { penginapan, pengangkutan, bekalan air, tenaga dan } \\
\text { sebagainya. }\end{array}$ \\
\hline Ekologi & $\begin{array}{l}\text { Menumpukan kepada kemampuan alam semulajadi seperti } \\
\text { flora, fauna, tanah, air dan udara menampung kesan } \\
\text { pelancongan. Ini sukar diukur terutamanya ekosistem yang } \\
\text { sensitif. }\end{array}$ \\
\hline Sosial & $\begin{array}{l}\text { Menumpukan kepada kemampuan sosiobudaya di mana } \\
\text { aktiviti pelancongan memberi kesan kepada komuniti. } \\
\text { Kesesakan dan perubahan budaya merupakan contoh yang } \\
\text { sesuai. }\end{array}$ \\
\hline
\end{tabular}




\begin{tabular}{|l|l|}
\hline Ekonomi & $\begin{array}{l}\text { Menumpukan kepada pengenalan aktiviti ekonomi yang baru } \\
\text { tanpa meminggirkan aktiviti ekonomi tradisional komuniti. } \\
\text { Ini menumpukan kesan pelancongan musiman kepada } \\
\text { destinasi dan tenaga buruh. }\end{array}$ \\
\hline Politik & $\begin{array}{l}\text { Menumpukan kepada keadaan politik semasa, tampungan } \\
\text { organisasi, kerjasama awam dan swasta dan penyertaan } \\
\text { penduduk dalam membuat keputusan. (decision making) }\end{array}$ \\
\hline
\end{tabular}

Sumber: Diubahsuai Daripada daripada Mandke (2001).

Merujuk kepada Jadual 2, had daya tampung terdiri daripada 5 dimensi utama meliputi ekologi, fizikal, sosial, ekonomi dan politik. Penggunaan had daya tampung adalah sesuai untuk diaplikasikan di semua kawasan dan destinasi pelancongan. Ini kerana setiap destinasi pelancongan itu mempunyai daya tampungannya sendiri terhadap jenis aktiviti dan pembangunan yang dilakukan. Teknik ini turut diaplikasi di kawasan yang dilindungi serta kawasan sensitif alam sekitar seperti Pulau Perhentian (Taman Laut) (Ibrahim \& Ahmad, 2012). Kawasan yang mempunyai ekosistem yang berteraskan alam semulajadi amat sesuai menggunakan teknik had daya tampung ini kerana taman laut seperti Pulau Perhentian adalah amat sensitif terhadap sebarang bentuk pembangunan yang dijalankan.

Penentuan had daya tampungan sebenarnya mempunyai pengiraan sendiri dan perlu mengambilkira pelbagai dimensi seperti yang disebut dalam Jadual 2. Namun dalam konteks perbincangan ini kajian akan memfokus kepada kaedah yang telah dijalankan oleh kerajaan melalui Pelan Ekopelancongan Kebangsaan (PEK). Hal ini, kerana pelan ini lebih tepat untuk digambarkan dengan situasi dan bentuk mukabumi bagi destinasi pelancongan di Malaysia. Untuk konsep Had Daya Tampung ini, melalui PEK telah mengemukakan formula bagi pengiraan had daya tampungan di destinasi pelancongan untuk digunakan di Malaysia iaitu:

Keupayaan Had Daya Tampungan = Kawasan yang digunakan pelancong

Purata Piawaian Individu (MOTAC 1997)

Kawasan yang digunakan pelancong dibahagikan dengan purata ruang piawaian individu (lazimnya diukur menggunakan meter persegi/individu). Walaubagaimanapun, piawaian individu berbeza antara manusia dan tempat. Sebagai contoh, pelancong merasa selesa berdiri bersama-sama 20 orang 
yang lain di sebuah kedai tetapi tidak di puncak gunung (Kementerian Kebudayaan, Kesenian dan Pelancongan, 1996).

Jumlah bilangan lawatan harian dibenarkan boleh diperoleh seperti kiraan berikut:

Jumlah Lawatan Harian = Had Daya Tampungan X Pekali Silih Berganti Di mana pekali silih berganti ditentukan dengan:

Pekali Silih Berganti = Jumlah Masa Kawasan dibuka kepada pelancong

Purata Tempoh Lawatan

Mengikut Pelan Ekopelancongan Kebangsaan yang telah digariskan, kerajaan Negeri Terengganu dengan kerjasama Kementerian Pelancongan Malaysia berusaha mengaplikasi teknik ini dalam mengkaji had daya tampung di Pulau Perhentian. Status Pulau Perhentian sebagai Taman Laut dan bersifat mesra alam sekitar memerlukan pengawalan kegiatan pembangunan pelancongan secara serius (Ibrahim \& Ahmad, 2012). Terdapat tiga tahap destinasi pelancongan yang boleh diambil panduan dalam mengkaji had daya tampung seperti yang telah digariskan oleh Kementerian Kebudayaan, Kesenian Dan Pelancongan (1996). Setiap destinasi pelancongan ini mempunyai had daya tampung mengikut pengklasifikasian tahap seperti Jadual 3.

Jadual 3: Had Daya Tampungan Yang Digariskan Melalui Pelan Eko-pelancongan Kebangsaan

\begin{tabular}{|l|l|}
\hline Tahap & Had Daya Tampungan yang Dicadangkan \\
\hline 1 & $0-999$ orang/tahun \\
\hline 2 & $1,000-99,999$ orang setahun \\
\hline 3 & 100,000 orang ke atas setahun \\
\hline
\end{tabular}

Sumber: Kementerian Kebudayaan, Kesenian dan Pelancongan (1996).

Merujuk kepada Jadual 3, dalam kes Pulau Perhentian, had daya tampungan yang dicadangkan adalah pada tahap 3 iaitu melebih 100,000 orang ke atas setahun. Pulau Perhentian mampu menerima dan menampung pelancong dalam kapasiti yang ramai namun masih amat perlu dikawal kerana dikhuatiri menjejaskan status pulau berkenaan sebagai pulau Taman Laut yang kaya dengan sumber alam dan hidupan lautnya. Pengkaji turut menjalankan soal selidik terhadap komuniti setempat terhadap cadangan untuk mengawal kedatangan pelancong ke Pulau Perhentian dalam skala yang lebih kecil bagi 
mengekalkan keistimewaan pulau berkenaan sebagai pulau Taman Laut. Jadual 4 menunjukkan hasil yang diperolehi melalui soal selidik terhadap 250 responden yang terdiri daripada komuniti setempat.

Jadual 4: Kesan Negatif Ke Atas Sosial Masyarakat Boleh Dikurangkan Dengan Mengawal Bilangan Pelancong Di Destinasi Kajian

\begin{tabular}{|l|l|l|l|l|}
\hline & Kekerapan & Peratusan \% & $\begin{array}{l}\text { Peratusan } \\
\text { Sah \% }\end{array}$ & $\begin{array}{l}\text { Peratusan } \\
\text { Terkumpul \% }\end{array}$ \\
\hline YA & 114 & 45.6 & 45.6 & 45.6 \\
TIDAK & 136 & 54.4 & 54.4 & 54.4 \\
JUMLAH & 250 & 100.00 & 100.0 & 100.0 \\
\hline
\end{tabular}

Sumber: Kajian Lapangan, 2015.

Melalui pertemuan dengan En. Zainuddin B. Mohammad selaku Ketua Kampung di pulau berkenaan beliau berkata, hampir separuh dari keseluruhan penduduk tidak bersetuju dengan konsep had daya tampung iaitu mengawal bilangan dan kemasukan pelancong. Hal ini kerana, penduduk tempatan sangat bergantung kepada aktiviti pelancongan terutamanya dalam membantu mereka meningkatkan hasil pendapatan.

Sehubungan itu, pihak berwajib amat perlu memainkan peranan dalam menyampai dan menerangkan secara terperinci kepentingan konsep ini dalam menjaga ekosistem yang ada di pulau berkenaan. Hal ini kerana, kemasukan pelancong yang melebihi had daya tampung yang ditetapkan akan menjanakan kesan negatif terhadap sumber jaya alam semula jadi seperti kerosakan denai (trail), hakisan tanah, kerosakan habitat flora dan fauna serta kerosakan ekosistem sedia ada.

\section{Kod Etika Pelancong}

Kod Etika Pelancong amat penting dalam mengurangkan kesan negatif terhadap pembangunan pelancongan. Kod Etika Pelancongan merupakan garis panduan kepada pelancong dan pengusaha pelancongan mengenai aktivitiaktiviti yang boleh dilakukan atau tidak boleh dilakukan di sesebuah destinasi pelancongan. Garis panduan yang dikemukakan dalam kod ini adalah bagi meminimakan kesan negatif dan memaksimakan kesan positif terhadap alam sekitar, ekosistem dan sosioekonomi di sesebuah destinasi pelancongan.

Mengikut Saudara Seman B. Muda wakil daripada Koperasi yang merupakan salah seorang wakil yang diamanahkan untuk berurusan dengan 
pihak MDB, kod etika berkenaan telah diwajibkan oleh Kerajaan Negeri Terengganu melalui pihak MDB supaya para pengusaha pelancongan di Pulau Perhentian meletakkannya di tempat strategik seperti di pintu masuk utama destinasi atau lokasi-lokasi tumpuan pelancong dalam bentuk brosur, risalah atau papan tanda. Kod Etika Pelancong yang telah diselaraskan oleh pihak kerajaan adalah seperti Jadual 5.

Jadual 5: Kod Etika Pelancongan di Pulau Perhentian

\begin{tabular}{|l|l|}
\hline No. & Kod Etika Pelancong \\
\hline 1 & Menghormati keunikan bumi dan membantu memeliharanya. \\
\hline 2 & $\begin{array}{l}\text { Dilarang membuang sampah merata-rata dan tidak mengambil } \\
\text { "cenderahati" dari kawasan alam semulajadi. }\end{array}$ \\
\hline 3 & $\begin{array}{l}\text { Lakukan perjalanan bermakna dengan meningkatkan usaha } \\
\text { pemeliharaan. }\end{array}$ \\
\hline 4 & $\begin{array}{l}\text { Dilarang membeli produk yang diperbuat daripada haiwan atau } \\
\text { tumbuhan yang dilindungi. }\end{array}$ \\
\hline 5 & $\begin{array}{l}\text { Pelancong perlu mengikut laluan yang ditetapkan, dilarang } \\
\text { mengganggu haiwan dan merosakkan tumbuhan daripada habitat } \\
\text { asal. }\end{array}$ \\
\hline 6 & $\begin{array}{l}\text { Mempelajari dan menyokong program-program berkaitan } \\
\text { pemeliharaan dan organisasi yang melakukan program } \\
\text { pemeliharaan. }\end{array}$ \\
\hline 7 & $\begin{array}{l}\text { Pastikan tapak perkhemahan dalam keadaan bersih sebelum } \\
\text { meninggalkannya. }\end{array}$ \\
\hline 8 & $\begin{array}{l}\text { Dilarang melakukan pembakaran unggun api di tapak } \\
\text { perkhemahan. }\end{array}$ \\
\hline 9 & $\begin{array}{l}\text { Sisa makanan yang dibawa perlu dibuang di tempat yang } \\
\text { disediakan ataupun membawa keluar sendiri dari kawasan ini. }\end{array}$ \\
\hline 10 & \begin{tabular}{l} 
Dilarang memancing di kawasan Taman Laut. \\
\hline
\end{tabular}
\end{tabular}

Sumber: Kajian Lapangan, 2015.

Kod etika juga diperkenalkan bagi menggalakkan pihak kerajaan dan swasta memfokuskan penjagaan alam sekitar dalam pembangunan pelancongan di Pulau Perhentian. Kod etika seperti Pacific Asia Travel Association (PATA) diperkenalkan sebagai garis panduan kepada negara-negara anggota dalam membangunkan pelancongan. Ianya lebih kepada pembangunan pelancongan yang tidak mengabaikan alam sekitar sebagai asas pembangunan pelancongan. Negara-negara yang ingin melakukan pembangunan pelancongan harus merujuk kepada kandungan kod etika PATA ini. (Verocai, \& Vanclay 2000) 


\section{Penilaian Kesan Sosial}

Penilaian kesan sosial merupakan proses untuk menilai dan menguruskan kesan daripada perlaksanaan projek, rancangan, program dan polisi ke atas penduduk (WTO, 1999). Ianya turut dikenali sebagai alat perancangan yang digunakan bagi mengawal dan menyelaras sesebuah projek, program, perancangan serta perubahan polisi semasa dan akan datang. Secara umumnya, perlaksanaan Social Impact Assesment (SIA) di Malaysia wujud sejak Akta Kualiti Alam Sekeliling 1974 (Pindaan 1985) Seksyen 34A serta Perintah Kualiti Alam Sekeliling (Aktiviti yang Ditetapkan) (Penilaian Kesan Kepada Alam Sekeliling), 1987 dikuatkuasakan.

Jadual 6: Peringkat-peringkat Projek/Program Mengikut Penilaian Kesan Sosial dan Huraian

\begin{tabular}{|l|l|}
\hline Peringkat & Huraian \\
\hline Perancangan Dasar & $\begin{array}{l}\text { Peringkat di mana projek/program belum } \\
\text { dilaksanakan yang tiada kesan ke atas sosial. } \\
\text { Melibatkan reka bentuk projek, penyemakan, } \\
\text { komen penduduk, perlesenan, penilaian beberapa } \\
\text { alternatif dan membuat keputusan. }\end{array}$ \\
\hline Pembinaan & $\begin{array}{l}\text { Peringkat perlaksanaan berlaku setelah diberi } \\
\text { kebenaran daripada aspek undang-undang. } \\
\text { Pelbagai altiviti projek/program dijalankan dan } \\
\text { menjanakan pelbagai kesan kepada sosial } \\
\text { penduduk positif dan negatif) }\end{array}$ \\
\hline Operasi & $\begin{array}{l}\text { Peringkat pembinaan projek telah siap dan } \\
\text { beroperasi di mana penduduk merupakan } \\
\text { sebahagian daripada projek tersebut. } \\
\text { Mengambil kira komuniti daripada aspek ekonomi } \\
\text { dan sosial jangka masa panjang. } \\
\text { Peringkat di mana projek/program yang } \\
\text { dilaksanakan akan tamat pada sesuatu masa. } \\
\text { Memberikan kesan langsung dan tidak langsung } \\
\text { kepada penduduk daripada aspek ekonomi dan } \\
\text { sosial akibat pelaksanaan projek tersebut. }\end{array}$ \\
\hline Peninggalan & \multicolumn{1}{|c|}{} \\
\hline
\end{tabular}


Sumber: Diubahsuai daripada "The Interorganizational Committee on Guidelines and Principles for Social Impact Assessment (1994)" dalam Ibrahim dan Mohamad Zaki Ahmad (2012).

Ia terkandung dalam Laporan "Environment Impact Assesment" (EIA) mengenal pasti kesihatan dan keselamatan, sosial dan ekonomi serta estetik dan kebudayaan sebagai 3 aspek di bawah kemanusiaan. Sebanyak empat peringkat projek atau program meliputi perancangan dasar, pembinaan, operasi dan peninggalan. Perincian bagi keempat-empat peringkat ini seperti Jadual 6.

\section{Piawaian Reka Bentuk}

Piawaian reka bentuk merupakan salah satu langkah yang digunapakai oleh pihak pemerintah dalam proses pembangunan terutamaya bagi destinasi pelancongan. Ianya antara lain bertujuan meminimumkan kesan negatif pembangunan terhadap alam sekitar. Pembangunan pelancongan sesebuah destinasi atau produk pelancongan meliputi penyediaan pelbagai komponen kemudahan dan perkhidmatan kepada pelancong. Sebagai contoh, English Tourist Board mencadangkan beberapa kriteria yang perlu diambil kira oleh pengusaha semasa merancang dan membina kemudahan. Kriteria yang dicadangkan oleh English Tourist Board adalah seperti Jadual 7.

Jadual 7: Kriteria Piawaian Reka Bentuk Terhadap Pembangunan Pelancongan

\begin{tabular}{|l|l|}
\hline No. & Kriteria. \\
\hline 1. & Menerapkan seni bina dan material tempatan bagi bangunan. \\
\hline 2. & $\begin{array}{l}\text { Mengambil kira ciri-ciri fizikal tapak dan menyesuaikan dengan reka } \\
\text { bentuk. }\end{array}$ \\
\hline 3. & $\begin{array}{l}\text { Memikirkan ciri-ciri reka bentuk yang boleh meminimumkan } \\
\text { penggunaan sumber dan tenaga. Contohnya, penggunaan tumbuhan } \\
\text { sebagai teduhan dan meminimumkan penggunaan penghawa dingin. }\end{array}$ \\
\hline 4. & $\begin{array}{l}\text { Menggunakan teknik pembinaan yang boleh meminimumkan kesan } \\
\text { negatif terhadap alam sekitar. }\end{array}$ \\
\hline 5. & $\begin{array}{l}\text { Menggunakan material kitar semula sebanyak mungkin. } \\
\text { penggunakan tumbuhan bagi tujuan landskap dan meningkatkan }\end{array}$ \\
\hline 6. &
\end{tabular}

Sumber: KPKT (2011). 
Piawaian reka bentuk kebanyakannya bersifat boleh ubah di mana garis panduannya berubah mengikut destinasi pelancongan yang hendak di bangunkan. Destinasi pelancongan yang melibatkan sumber alam dan ekosistem memerlukan garis panduan piawaian reka bentuk yang lebih teliti bagi mengelakkan berlakunya kesan negatif terhadap alam dan juga ekosistem. Dalam konteks pulau Taman Laut, mana-mana pembangunan yang dibuat samada oleh pihak kerajaan, pengusaha (swasta) perlu merujuk kepada Laporan Tahap Tampungan serta Garis Panduan Pembangunan atau lain-lain peraturan yang telah disediakan untuk pulau-pulau taman laut. Namun, dalam proses pembangunan pelancongan di destinasi taman laut, aktiviti pembangunan hendaklah tidak membahayakan alam semulajadi meliputi ekosistem sedia ada seperti terumbu karang, hidupan marin seperti yang tertakluk kepada peruntukan Syeksen 41 hingga Syeksen 45, Akta Perikanan 1985.

Bagi piawaian perancangan bangunan dan jalan di kawasan Pulau Perhentian pula, iainya mesti mengikut garis panduan seperti anjakan belakang, ruang legar, dan sebagainya. Anjakan belakang iaitu antara hujung bangunan dengan bangunan dengan mana-mana sempadan lot ialah 1.5 meter dan jarak antara hujung bangunan dengan hujung bangunan ialah 3 meter seperti Rajah 1. Aspek anjakan perlu disemak sama ada anjakan di kawasan pulau adalah sama dengan kawasan daratan. Sementara itu, dari aspek ruang legar (clear space) bagi kawasan yang tidak bersempadan dengan lorong belakang, ruang legar ialah 4 meter seperti Rajah 2 .

Rajah 1: Anjakan Belakang/Ruang Legar (Kawasan Kediaman)

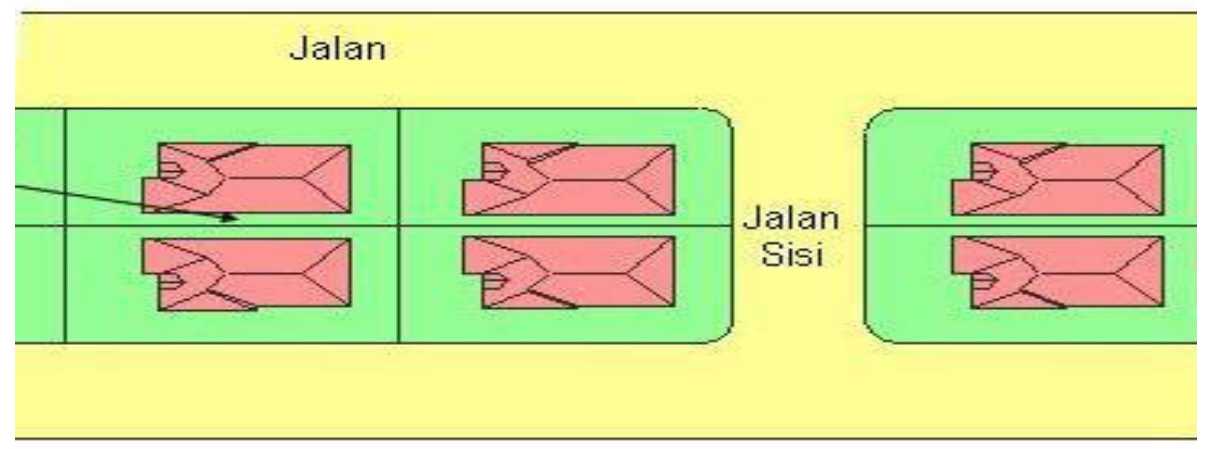


Rajah 2: Ruang Legar Bagi Kawasan Kediaman

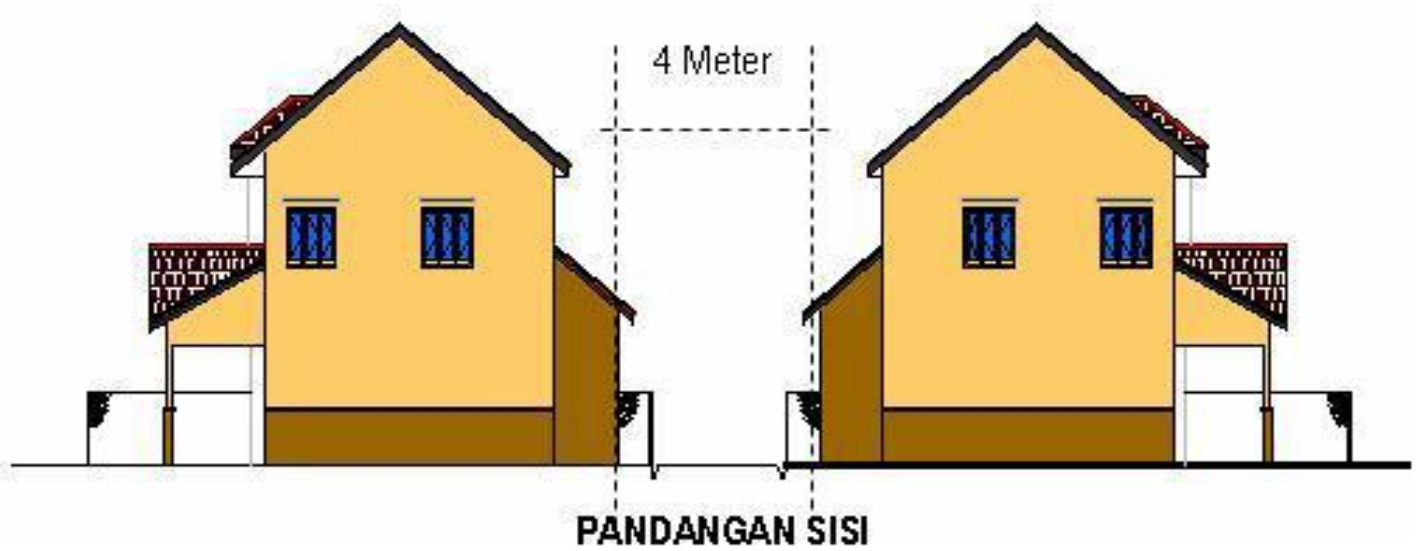

Sementara itu, bagi bangunan yang mengadap rizab jalan utama, jarak antara garis bangunan dengan rizab jalan adalah 4 meter seperti Rajah 3.

Rajah 3: Jarak Antara Garis Bangunan Dengan Rizab Jalan (Kediaman)

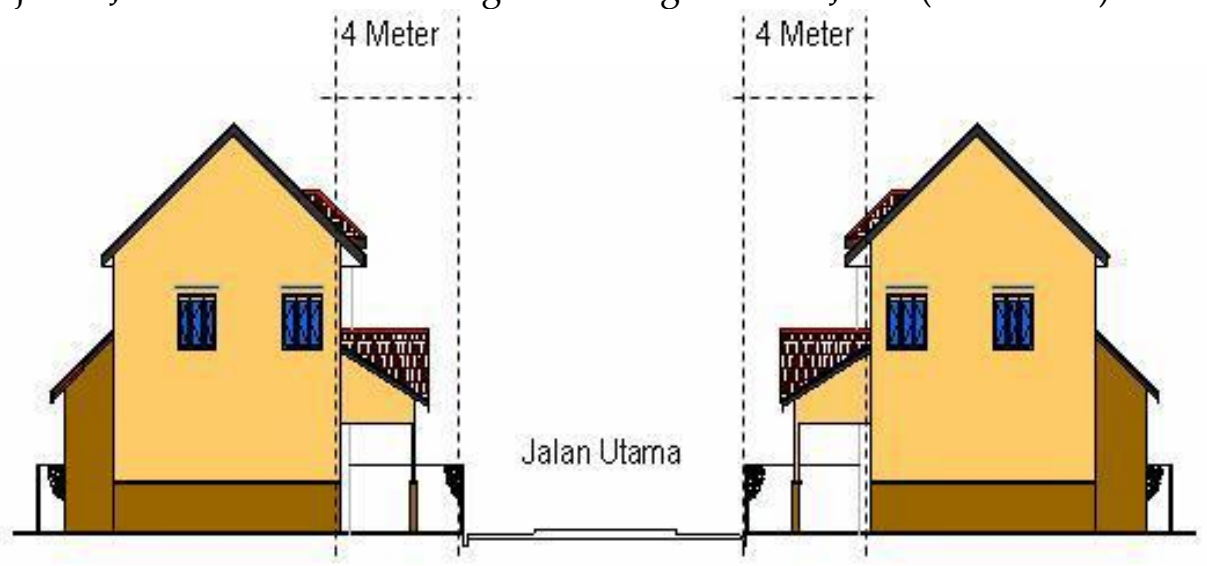

Rizab dan lebar jalan pula perlu diikuti dalam proses pembangunan rumah penduduk. Rizab jalan utama dalam perumahan ialah 3.5 meter bagi 
jalan sehala seperti Rajah 4. Rizab lorong belakang pula ialah 3.5 meter seperti Rajah 5.

Rajah 4: Rizab dan Lebar Jalan

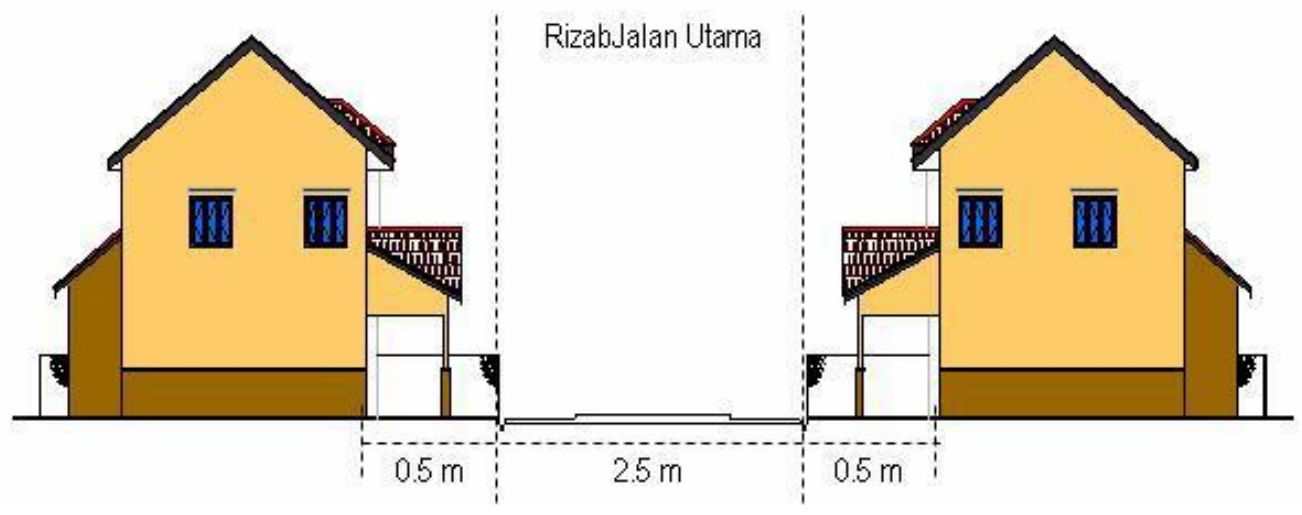

JALAN SEHALA

Rajah 5: Rizab Lorong Belakang/sisi

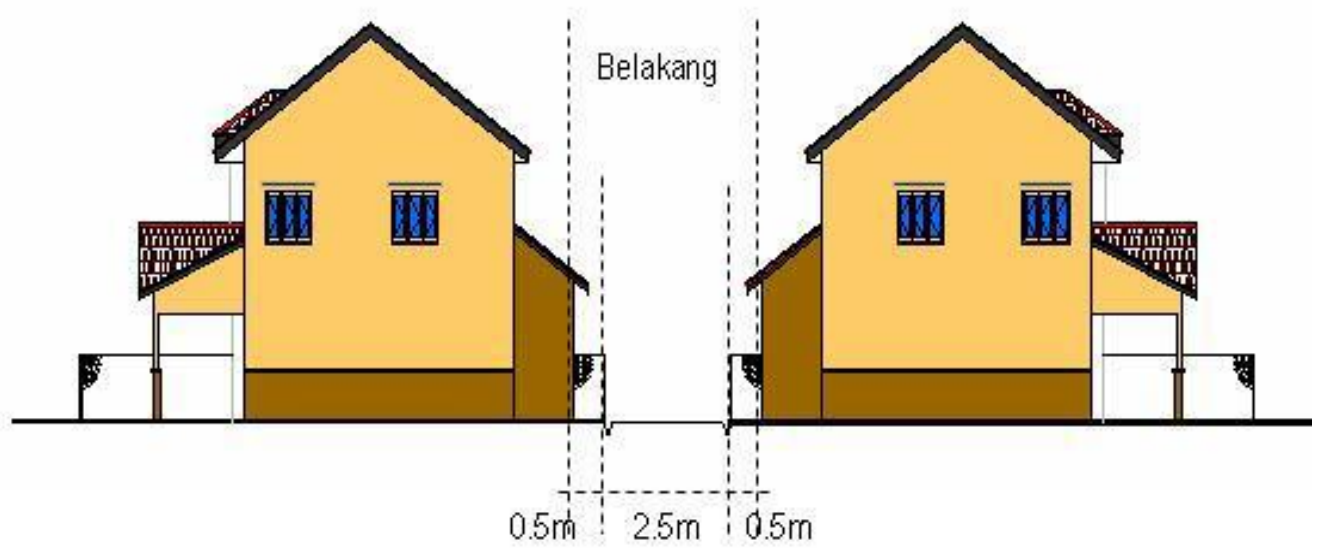

Sumber: KPKT (2011). 
Garis piawaian reka bentuk ini perlu diaplikasikan oleh semua pihak atau pengusaha pelancongan di destinasi pelancongan Pulau Taman laut. Hal ini kerana ekosistem di Pulau Taman Laut adalah amat sensitif kepada sebarang perubahan berbentuk fizikal. Perubahan ini dikhuatiri akan meningkatkan kesan negatif pembangunan seterusnya akan merosakkan ekosistem sedia ada. Selain itu, terdapat beberapa langkah yang perlu dilaksanakan dalam menjaga proses pembangunan pelancongan yang stabil di Pulau Perhentian.

Jadual 8: Kualiti Hidup Meningkat Hasil Pembangunan Pelancongan Di Kawasan

\begin{tabular}{|l|r|r|c|c|}
\hline \multicolumn{5}{|c|}{ Kajian } \\
\hline TIDAK SETUJU & 2 & $\begin{array}{c}\text { Peratusan } \\
\%\end{array}$ & $\begin{array}{c}\text { Peratusan } \\
\text { Sah } \%\end{array}$ & $\begin{array}{c}\text { Peratusan } \\
\text { Terkumpul }\end{array}$ \\
SETUJU & 183 & 73.2 & 0.8 & 0.8 \\
SANGAT SETUJU & 65 & 26.0 & 26.0 & 74.0 \\
JUMLAH & 250 & 100.0 & 100.0 & 100.0 \\
\hline
\end{tabular}

Sumber: Kajian Lapangan, 2015.

Berdasarkan Jadual 8, hasil kajian menunjukkan, sebanyak $73.2 \%$ daripada komuniti setempat bersetuju bahawasanya kualiti hidup mereka meningkat hasil proses pembangunan pelancongan yang dijalankan di Pulau Perhentian. Sehubungan itu, pembangunan melalui piawaian reka bentuk telah banyak membantu penduduk setempat dalam menambahbaik kualiti hidup mereka samada dari sudut pendapatan harian mahupun kemudahan akses kepada pembangunan yang mampan seperti yang dapat dilihat pada Jadual 9. Jadual 9 menunjukkan penguatkuasaan piawaian bagi pembangunan pelancongan fizikal berasaskan amalan kemampanan antarabangsa yang dilaksanakan di Pulau Perhentian.

Jadual 9: Penguatkuasaan Piawaian Bagi Pembangunan Pelancongan Fizikal Berasaskan Amalan Kemampanan Antarabangsa Di Pulau Perhentian

\begin{tabular}{|l|l|ll|}
\hline & Langkah-langkah & Agensi Pelaksana & \\
\hline 1 & $\begin{array}{l}\text { Memudahkan proses penyediaan } \\
\text { bekalan 24 jam, rawatan air kumbahan }\end{array}$ & SATU (Syarikat & Air \\
berpusat dan kemudahan untuk & Terengganu) & \\
berpusat dan kemudahan untuk & Operator Resort & \\
pengkomposan sisa organik dan lain- & & \\
\hline
\end{tabular}




\begin{tabular}{|c|c|c|}
\hline & lain. & \\
\hline 2 & $\begin{array}{l}\text { Pembangunan masa hadapan tertakluk } \\
\text { kepada piawaian yang ketat } \\
\text { berdasarkan amalan kemampanan } \\
\text { antarabangsa dalam pembangunan } \\
\text { resort yang mampan termasuk kitar } \\
\text { semula, pengumpulan air hujan, usaha } \\
\text { penjimatan tenaga dan sisa rawatan air } \\
\text { yang efisyen. }\end{array}$ & $\begin{array}{l}\text { JPBD } \\
\text { Pihak Berkuasa Tempatan }\end{array}$ \\
\hline 3 & $\begin{array}{l}\text { Memperkenalkan program anugerah } \\
\text { tahunan bagi amalan kemampanan } \\
\text { dalam pembangunan resort yang } \\
\text { mampan dengan menawarkan } \\
\text { ganjaran wang tunai dan lawatan } \\
\text { teknikal yang dibayar sepenuhnya ke } \\
\text { tempat-tempat yang menjadi contoh } \\
\text { kejayaan antarabangsa. }\end{array}$ & $\begin{array}{l}\text { Tourism Terengganu } \\
\text { KETHHA }\end{array}$ \\
\hline
\end{tabular}

Sumber: Diubahsuai daripada Laporan Akhir Perhentian Ecotourism Plan 2015.

\section{Kesimpulan}

Pembangunan pelancongan sememangnya memberikan kesan yang cukup positif ke atas sesebuah destinasi pelancongan seperti Pulau Perhentian. Destinasi pelancongan berbentuk pulau dan maritim adalah kategori destinasi yang sangat mudah menerima perubahan dari segi ekosistem sekiranya aktiviti pembangunan pelancongan dijalankan tanpa panduan khusus. Pembangunan yang tidak berpaksikan kepada kelestarian atau pembangunan mampan akan menyebabkan ekosistem, flora dan fauna akan terjejas seterusnya membawa kesan buruk terhadap ketibaan pelancong dalam jangka masa yang panjang. Contoh yang jelas adalah penebangan pokok-pokok di sekitar Long Beach di Perhentian Kecil bagi tujuan pembinaan Chalet dan Resort haram menyebabkan berlakunya kesan ke atas alam sekitar seperti hakisan yang teruk. Hal ini sekaligus menyebabkan laluan air yang terhasil secara semulajadi selepas hujan, tersekat dan menyebabkan kerosakan kepada permukaan tanah di sekitar Long Beach. Untuk itu, dengan perlaksanaan pembangunan pelancongan mampan, maka ia mampu memberi kesan positif kepada sosioekonomi dan budaya masyarakat di destinasi pelancongan. Pemantauan dan tindakan segera daripada pelbagai pihak yang berkaitan adalah amat perlu dalam menjamin kestabilan ekosistem yang wujud secara semulajadi di Pulau 
Perhentian. Elemen kelestarian atau kemampanan adalah amat perlu dipraktikkan dalam setiap perancangan dan aktiviti pembangunan sedia ada bagi memastikan sumber daya di Pulau Perhentian dipelihara dan terus dikunjungi oleh pelancong dalam jangkamasa panjang.

\section{Rujukan}

Ibrahim, J. E., \& Ahmad, M. Z. (2012). Perancangan dan Pembangunan Pelancongan. Sintok: Penerbit UUM.KPKT. (2011). Garis Panduan Perancangan (GPP) Fizikal Pulau-pulau Taman Laut. Putrajaya: Jabatan Perancangan Bandar dan Desa Semenanjung Malaysia, Kementerian Perumahan dan Kerajaan Tempatan.

Mandke, P. , et al. (2001). Carrying Capacity as a tool for tourism management, community tourism destination management: Principles and practices. Canada, Canadian Universities Consortium Urban Environmental Management Project.

Mohd. Ariff, M. D., Selvaraju, M., \& Md. Yusop, M. E. (2005). Commonalities In Intra-ASEAN Tourism: Harnessing The Power of 10. JATI, 10(1), 91107.

MOTAC. (1997). Pelan Ekopelancongan Kebangsaan. Kementerian Pelancongan dan Kebudayaan Malaysia.

Nanthakumar, L., \& Thirunaukarasu, S. (2005). Pola Kemiskinan Dinamik Masyarakat Pulau dan Pesisiran Pantai: Kajian Kes Pulau Perhentian. JATI, 10(1), 151-169.

UMT (2012, April). Pelan Pembangunan Penduduk dan Pelancongan Lestari Pulau Perhentian. Kuala Terengganu, Universiti Malaysia Terengganu.

Verocai, S. B. \& Vanclay, F. (2000). Environmental and Social Impact Assessment for Large Dams. Thematic Review. Cape Town: World Commison on Dams.

Weaver, D. B. (1998). Ecotourism in the less developed world. New York: CAB International.

WTO. (1999). International tourism: A global perspective. Retrieved from https://www.wto.org/.

WTO. (2015). Carrying Capacity. Retrieved from https://www.wto.org/. 